\title{
EFEKTIVITAS TRAINING EFIKASI DIRI TERHADAP KEPATUHAN PEMBATASAN CAIRAN DAN NILAI INTRADIALYTIC WEIGHT GAIN PASIEN GAGAL GINJAL KRONIK YANG MENJALANI HEMODIALISA DI RS X MAKASSAR
}

\section{[THE EFFECTIVENESS OF SELF-EFFICACY TRAINING ON COMPLIANCE WITH FLUID RESTRICTIONS AND INTRADIALYTIC WEIGHT GAIN VALUE FOR PATIENTS WITH CHRONIC RENAL FAILURE UNDERWENT HEMODIALYSIS IN HOSPITAL X MAKASSAR]}

\author{
Adolfina Lukas Siamben ${ }^{1}$, Maria Astrid ${ }^{2}$, Sutanto Priyo Hastono ${ }^{3}$ \\ Program Magister Keperawatan STIK Sint Carolus Jakarta ${ }^{1}$ \\ e-mail : lukasadolfina@gmail.com \\ DOI : 10.47718/jpd.v8i02.1187
}

ABSTRAK

\begin{abstract}
Latar belakang : Peningkatan berat badan intradialitik akibat ketidakpatuhan asupan cairan pasien yang menjalani hemodialisa berdampak pada terjadinya penumpukan cairan secara kronis dan berisiko terhadap gangguan pada kardiovaskuler dan hipertensi, serta meningkatkan mortalitas dan morbiditas pada pasien gagal ginjal kronik. Tujuan: Penelitian ini menganalisis efektivitas Training Efikasi Diri terhadap kepatuhan pembatasan cairan dan nilai Intradialytic Weight Gain (IDWG) terhadap pasien gagal ginjal kronik yang menjalani hemodialisis. Metode : Penelitian dilakukan pada Juni-Juli 2020 di RS. Stella Maris Makassar. Penelitian ini merupakan penelitian kuantitatif dengan desain quasy experiment pre-post-test dengan control group terhadap 92 responden (69 di kelompok intervensi dan 23 di control). Intervensi Traning Efikasi Diri diberikan sesuai dengan Booklet selama 4 minggu, seminggu 3 kali dengan total 12 kali pertemuan. Kepatuhan dinilai dengan kuesioner sebelum dan sesudah penelitian serta observasi berat badan setiap kali kunjungan untuk menghitung nilai Intradialytic Weight Gain. Hasil : Hasil uji T Dependen Parametrik Terdapat perbedaan antara kepatuhan pembatasan cairan $(p<0.05)$ dan nilai Intradialytic Weight Gain $(p<0.05)$ sebelum dan sesudah intervensi. Uji T independen Parametrik terdapat perbedaan signifikan kepatuhan pembatasan cairan $(\mathrm{p}<0.05)$ dan nila Intradialytic Weight Gain $(p<0.05)$ antara kelompok intervensi dengan kontrol. Hasil uji Ancova, Training efikasi diri berpengaruh terhadap kepatuhan pembatasan cairan sebanyak 17,7\%, sementara $82,3 \%$ dipengaruhi oleh variabel lain di luar penelitian. Training efikasi diri sangat berpengaruh terhadap nila Intradialytic Weight Gain sebanyak 18,5\%, sementara 81,5\% dipengaruhi oleh variabel lain diluar penelitian.
\end{abstract}




\section{ABSTRACT}

Kesimpulan: Training efikasi diri sebagai salah satu jenis terapi komplementer untuk meningkatkan kepatuhan pembatasan cairan dan nila Intradialytic Weight Gain penderita GGK dengan hemodialisa.

Kata Kunci : Gagal Ginjal Kronik, Kepatuhan Pembatasan Cairan, Nilai IDWG Dan Training Efikasi Diri

Introduction: Increased intradialytic body weight due to non-compliance with fluid intake of patients undergoing hemodialysis has an impact on chronic fluid accumulation and is at risk for cardiovascular disorders and hypertension, as well as increasing mortality and morbidity in patients with chronic renal failure. Aim: This study analyzed the effectiveness of Self Efficacy Training on fluid restriction compliance and the value of Intradialytic Weight Gain (IDWG) for chronic renal failure patients undergoing hemodialysis. Methods: The study was conducted in June-July 2020 at the hospital. Stella Maris Makassar. This research is a quantitative study with a quasy experimental pre-post-test design with a control group of 92 respondents (69 in the intervention group and 23 in the control). Self Efficacy Training Interventions were given in accordance with the Booklet for 4 weeks, 3 times a week with a total of 12 meetings. Adherence was assessed by means of a pre- and post-study questionnaire and weight observation at each visit to calculate the intradialytic weight gain value. Results: Parametric Dependent $T$ test results. There was a difference between compliance with fluid restriction $(p<0.05)$ and the value of intradialytic weight gain $(p<0.05)$ before and after the intervention. Parametric independent $T$ test showed a significant difference in fluid restriction compliance $(p<0.05)$ and Intradialytic Weight Gain value ( $p$ $<0.05$ ) between the intervention and control groups. The results of the Ancova test, self-efficacy training affected compliance with fluid restriction by $17.7 \%$, while $82.3 \%$ were influenced by other variables outside the study. Self-efficacy training greatly influenced the Intradialytic Weight Gain value of $18.5 \%$, while $81.5 \%$ was influenced by other variables outside the study. Conclution: Self-efficacy training as a type of complementary therapy to improve adherence to fluid restriction and tilapia Intradialytic Weight Gain in CRF patients with hemodialysis.

Keywords: Chronic Renal Failure, Compliance with Fluid Restrictions, IDWG Value and Self Efficacy Training 


\section{PENDAHULUAN}

\section{Gagal ginjal terjadi apabila proses patofisiologi dengan etiologi}

yang beragam membuat ginjal tidak mampu lagi mengeluarkan sisa metabolisme dan menjalankan fungsi regulasinya sebagaimana mestinya. Bila hal ini terus berlanjut, maka pasien akan mengalami suatu keadaan yang disebut dengan gagal ginjal kronik atau End Stage Renal Disease (ESRD). Pada tahap ini telah terjadi pengurangan irreversible dan progresif dari jaringan ginjal sehingga penderita memerlukan terapi pengganti fungsi ginjal (renal replacement therapy) seperti hemodialisis ataupun transplantasi ginjal (Setiati et al., 2017; Brunner \& Suddarth, 2013; Black \& Hawks, 2014). Menurut National Kidney Foundation (NKF) mendefenisikan bahwa ESRD adalah kerusakan sebagai laju filtrasi glomelurus (GFR) $<15 \mathrm{ml} /$ menit/173 m2, (GFR) $<60 \mathrm{ml} /$ menit/1.73 m2 selama 3 bulan atau lebih terlepas dari penyebabnya dan kondisi ini membutuhkan terapi pengganti ginjal atau dialisis (Huether, L., \& Kathryn, 2019; Lewis et al., 2011). Menurut WHO (World Health Organization) pada tahun 2016 bahwa angka kejadian GGK di seluruh dunia mencapai $10 \%$ dari populasi dan, diperkirakan mencapai 1,5 juta orang di seluruh dunia menjalani hemodialisis pasien. Angka kejadiannya diperkirakan meningkat $8 \%$ setiap tahunnya dan menempati angka kematian tertinggi ke-20 di dunia. United Stage Renal Data System atau USRDS (2016) melaporkan bahwa prevalensi penderita GGK di Amerika Serikat mencapai 14,8\% dari tahun 2011-2014. Prevalensi gagal ginjal kronik akan terus mengalami peningkatan, di Taiwan 2.990/1.000.000 penduduk, Jepang 2.590/1.000.000 penduduk, dan 
Amerika Serikat 2.020/1.000.000 penduduk. Diperkirakan penderita GGK yang juga memiliki penyakit diabetes mencapai 40\%, 32\% memiliki penyakit hipertensi, dan $40 \%$ memiliki penyakit kardiovaskular. Selain itu tingkat kematian pada penderita GGK mencapai 134,8 per 1000 pasien/tahun, dimana angka kematian pada laki-laki lebih tinggi yaitu 50,8 per 1.00 dibandingkan dengan wanita yaitu pasien/tahun 41,1 per 1.000 pasien/tahun. Di Indonesia, jumlah pasien dengan GGK yang menjalani terapi hemodialisis mengalami peningkatan, dimana meningkat sekitar empat kali lipat dalam waktu 5 tahun terakhir (2011 sampai dengan 2016). Diperkirakan sekitar 150.000 orang penderita membutuhkan terapi hemodialisis, namun faktanya di tahun 2017 tercatat jumlah pasien menerima terapi hemodialisis sebesar 77.892 orang yang aktif sedangkan pasien baru sebanyak 30.843 orang Indonesian Renal Registry (IRR, 2017). Perhimpunan Nefrologi Indonesia (PERNEFRI) melaporkan setiap tahunnya terdapat 200.000 kasus baru gagal ginjal stadium akhir. Berdasarkan laporan Indonesian Renal Registry atau IRR (2017), Jakarta Barat merupakan wilayah yang memiliki penderita gagal ginjal kronik yang menjalani hemodialisis terbanyak dibandingkan dengan kota-kota di Indonesia lainnya yakni mencapai 7444 jiwa pasien baru dan 21051 jiwa pasien aktif. Sulawesi menjadi peringkat ke-19 di Indonesia yang memiliki penderita GGK baru yang menjalani hemodialisis sebanyak 200 orang (IRR, 2017).

Hemodialisis merupakan terapi dialisis yang dilakukan seumur hidup oleh pasien penyakit ginjal stadium terminal, untuk 
mempertahankan keseimbangan normal cairan elektrolit serta membuang zat sisa secara artifisial. Pada saat hemodialisis darah pasien dipompa melalui selang selofan yang dikelilingi oleh sejumlah besar cairan dengan komposisi serupa dengan plasma normal. Terapi hemodialisis dilakukan 2 kali dalam seminggu selama 4-5 jam. Setelah proses dialisis, darah dikembalikan ke sistem sirkulasi pasien. Pada proses hemodialis, sekitar $250 \mathrm{~mL}$ darah berada diluar tubuh setiap waktunya (Sherwood, 2017).

Berdasarkan distribusi usia pasien hemodialisis, kelompok usia terbanyak adalah 45-64 tahun mencapai 31\%, sedangkan kelompok usia 15-24 tahun sekitar 2,26\% yang menjalani terapi hemodialisis memiliki persentase yang paling sedikit Indonesian Renal Registry atau IRR (2017). Prevalensi laki-laki (4,17 \%) lebih tinggi dari perempuan (3,52\%) dan insiden pada usia 15-24 tahun sekitar 1,33\%, usia 45-54 tahun sekitar 5,64\%, diikuti usia 55-64 tahun sekitar 7,21\% dan usia tertinggi 65-74 tahun sekitar 8,48\% (Riskesdas, 2018).

Berdasarkan data yang diperoleh dari RS. Stella Maris Makassar, menunjukkan bahwa pada tahun 2018 tercatat 135 orang pasien yang menjalani hemodialisis, sedangkan pada tahun 2019 tercatat 195 orang pasien yang menjalani hemodialisis di rumah sakit tersebut (Rekam Medik RS. Stella Maris Makassar, 2019). Dampak dari ketidakpatuhan pasien dalam pembatasan cairan adalah pasien mengeluh sesak, susah tidur, kram otot, mual dan muntah, oleh karena pelaksanaan tindakan untuk pembatasan cairan belum dilakukan secara maksimal dimana petugas kesehatan tidak selalu 
memberikan edukasi pembatasan cairan dari 15 perawat yang tugas di ruang hemodialisis sekitar (33\%) yang sering melakukan edukasi pembatasan cairan. Kurang lebih 20 pasien memiliki nilai Intradialytic Weight Gain (IDWG) > 3\% oleh karena tidak patuh terhadap pembatasan cairan. Belum ada program, jadwal dan booklet pemberian edukasi di unit Hemodialisis. Untuk leaflet Gagal Ginjal Kronik yang dibuat oleh Tim PKRS Rumah Sakit sudah ada tetapi tidak memuat tentang pemantauan cairan.

Kepatuhan pada program kesehatan merupakan perilaku yang dapat diobservasi sehingga dapat langsung diukur melalui hasil atau tujuan yang dicapai dalam program pengobatan yang telah ditentukan, dapat mencegah, meminimalkan komplikasi pada pasien hemodialisis serta faktor penting yang berkonstribusi untuk kelangsungan hidup dan kulitas hidup (Morton et al., 2012). Faktorfakor yang mempengaruhi kepatuhan adalah usia, jenis kelamin, pengetahuan, sikap, kepercayaan, motivasi, dukungan social dan sistem pelayanan kesehatan (Syamsiah, 2011). Masalah yang umum yang dialami oleh pasien yang sedang menjalani terapi hemodialisis berkaitan dengan ketidakpatuhan pembatasan cairan. Hal ini dapat memicu kelebihan cairan dalam tubuh. Kelebihan volume cairan dapat menyebabkan edema disekitar tubuh, kondisi inilah yang dapat membuat tekanan darah meningkat, memperberat kerja jantung dan juga dapat menyebabkan sesak napas. Hal lain yang terjadi pada pasien gagal ginjal kronik yang tidak membatasi cairan adalah peningkatan berat badan melebih berat badan normal 0,5 kg/24 jam 
(Sharaf, 2016). Keyakinan individu mengenai kemampuan yang dimiliki untuk melakukan sesuatu (self efficacy) berhubungan dengan perilaku kepatuhan pasien GGK yang menjalani hemodialisis. Perilaku ketidakpatuhan seseorang terhadap pengobatan akan berdampak pada kondisi/status kesehatannya. Termasuk kepatuhan dalam menjalani diet dan cairan pada penderita gagal ginjal. Ketidakpatuhan penderita dalam menjalani prinsip diet dan cairan yang dianjurkan dapat berdampak buruk bagi prognosis penyakitnya. Penelitian (Wulan \& Emaliyawati, 2018) menunjukkan bahwa kelebihan masukan cairan pada pasien GGK dengan hemodialisis akan meningkatkan mortalitas.

Indikator keberhasilan pasien HD mengelola cairan adalah dengan mengontrol kenaikan berat badan. Komplikasi jika Intradialytic Weight Gain (IDWG) bertambah (tidak normal) yaitu : hipertensi, hipotensi intradialisis, gagal jantung kiri, asites, pleural effusion dan gagal jantung kongestif (Williams, 2018). Peningkatan berat badan dalam waktu singkat dapat berarti peningkatan jumlah cairan dalam tubuh. Peningkatan berat badan yang mengindikasikan kelebihan cairan dikenal dengan Interdialytic Weight Gain (IDWG). Intradialytic Weight Gain (IDWG) merupakan peningkatan volume cairan yang dimanifestasikan dengan peningkatan berat badan sebagai dasar untuk mengetahui jumlah cairan yang masuk selama periode interdialitik (Istanti, 2014). Intradialytic Weight Gain (IDWG) yang dapat ditoleransi oleh tubuh tidak lebih dari 1,0-1,5 $\mathrm{kg}$ atau 3\% dari berat badan kering (Hill, R. Hall \& J. P, 2017). Semakin tinggi 
Intradialytic Weight Gain (IDWG) maka semakin besar jumlah kelebihan cairan dalam tubuh pasien dan semakin tinggi risiko komplikasi. Pembatasan masukan cairan pada pasien dengan gagal ginjal kronis diperlukan perhatian untuk mencegah terjadinya komplikasi. Semakin besar jumlah kelebihan cairan maka semakin tinggi Intradialytic Weight Gain (IDWG) dalam tubuh pasien (Neumann et al., 2013).

Keberhasilan menajemen cairan pada terapi hemodialisis dianalisa dengan Intradialytic Weight Gain (IDWG). Mengevaluasi bagaimana pasien mengatur intake cairan dengan Intradialytic Weight Gain (IDWG), yang di kalkulasi dalam kilogram atau sebagai persentasi berat badan kering pasien. Untuk menurunkan kelebihan cairan dalam tubuh diantara waktu dialisis, Intradialytic Weight Gain (IDWG) sebaiknya harus kurang dari $2,5 \mathrm{~kg}$ atau $5 \%$ dari berat badan diantara dua sesi dialisis (Sharaf, 2016). Dalam hal ini, megindikasikan bahwa pasien hemodialisis disarankan intake cairan perhari yang diperbolehkan adalah $500 \mathrm{ml}$ ditambah jumlah total urine output perhari. Di Amerika serikat, dilaporkan sebanyak 9,7\% 49,5\% pasien mengalami kenaikan Intradialytic Weight Gain (IDWG). Selain itu di Eropa, sebanyak 9,8\% - 70\% pasien mengalami kenaikan Intradialytic Weight Gain (IDWG) (Sharaf, 2016).

Hal yang mempengaruhi Intradialytic Weight Gain (IDWG) selama periode terapi hemodialisis salah satunya adalah efikasi diri (Priska \& Herlina, 2013). Peningkatan Intradialytic Weight Gain (IDWG) disebabkan oleh berbagai macam faktor baik faktor internal 
yang meliputui usia, jenis kelamin, tingkat pendidikan, rasa haus, stress, self fficacy, maupun faktor ekstrenal yaitu dukungan keluarga dan social serta jumlah intake cairan (Mustikasari \& Noorratri, 2017). Efikasi diri dapat didefiniskan sebagai proses individu dalam mencapai suatu kemajuan dan mampu melakukan kegiatan kehidupan sehari-hari sebanyak mungkin (Rahimi et al, 2017). Efikasi diri adalah memberikan keyakinan bahwa seseorang akan berhasil dalam melakukan perawatan dirinya asalkan optimal dalam melakukan kegiatan yang menunjang pada status kesehatan (Afandi, 2017; Mailani \& Andriani, 2017). Self-efficacy atau efikasi diri merupakan salah satu cara untuk meningkatkan kepercayaan diri dalam menjalani proses pengobatan yang menahun. Ketika pasien sudah divonis mengalami penyakit kronis seperti penyakit ginjal kronik dan harus menjalani hemodialisis, secara otomatis pasien akan melakukan tindakan supaya penyakitnya tidak bertambah parah, dalam hal ini efikasi diri berperan penting dalam pengambilan keputusan pasien.

Beberapa faktor yang berperan dalam mengembangkan efikasi diri adalah pra konsepsi terhadap kemampuan diri, kesimpulan diri tentang sulitnya tugas yang telah diselesaikan, serta adanya dukungan keluarga (Friedman, 2018). Hubungan yang erat dengan seseorang yang bisa dijadikan tempat untuk menumpahkan perasaannya pada saat-saat stress dan kehilangan semangat selama menjalani terapi hemodialisis yang cukup lama yang dapat diperoleh dari anggota keluarga dan membuat anggota keluarga menjadi lebih 
dekat satu sama lain (S. Smeltzer \& Bare, 2010).

Penelitian yang dilakukan oleh (Wijayanti et al., 2017) di RSUD Dr. Harjono Ponorogo kepada 38 responden didapatkan 20 responden $(52,63 \%)$ memiliki perilaku buruk dalam mengontrol cairan tubuh, sedangkan 18 responden (47,36\%) memiliki perilaku baik. Masukan cairan merupakan faktor yang berkontribusi secara signifikan terhadap Intradialytic Weight Gain (IDWG). Intradialytic Weight Gain (IDWG) lebih dari $2.5 \mathrm{~kg}$ menyatakan lemahnya kepatuhan pasien terhadap asupan cairan. Intradialytic Weight Gain (IDWG) berada dalam kisaran 2,5\% sampai 3,5\% dari berat badan kering untuk mengurangi risiko kardiovaskular dan juga untuk mempertahankan status gizi yang baik. Perilaku mengontrol cairan pada pasien hemodialisis dapat ditingkatkan dengan memberikan dukungan baik dari tenaga kesehatan dan keluarga pasien selama menjalani hemodialisis dan training efikasi diri.

Studi literatur sistematika review dan meta-analisis tentang ketidakpatuhan dengan pengobatan pada pasien gagal ginjal kronik yang menjalani dialisis yang dilakukan di Iran 2019 didapatkan hasil penyebab ketidakpatuhan yaitu : masalah psikososial dan psikologi, dukungan sosial, diri sendiri, sistem perawatan kesehatan, sistem terapi dan yang berhubungan dengan penyakit. Faktor-faktor tersebutlah yang menyebabkan ketidakpatuhan pasien dialisis terhadap pengobatan yang dapat menyebabkan keadaan pasien memburuk (Tayebi et al., 2019).

Selanjutnya sebuah penelitian yang dilakukan oleh (Mohebi et 
al., 2018) di Iran menilai pengaruh edukasi self efficacy teory pada kepatuhan terhadap diet dan pembatasan asupan cairan pasien hemodialisis. Dari hasil penelitian yang dilakukan kepada 70 pasien hemodialisis, ditemukan hasil bahwa ada perbedaan yang signifikan antara pre test dan post-test pada kelompok kontrol dengan nila $p<0,05$, edukasi self efficacy teory memiliki efek pada kepatuhan terhadap diet dan pembatasan cairan pada pasien dengan hemodialisis. Menurut (Sulistyaningsih, 2012) dengan hasil penelitian didapatkan training efikasi diri dapat meningkatkan kepatuhan terhadap cairan yang dimanifestasikan dengan penurunan rata-rata Intradialytic Weight Gain (IDWG) pada pasien setelah dilaksanakan training efikasi diri $p=0,008$.

Peran tenaga kesehatan khususnya perawat sebagai edukator pemberian pendidikan kesehatan kepada pasien masih sangat penting untuk dilakukan. Konsep pelayanan keperawatan dari model kuratif ke arah promotif dan prefentif mendorong lahirnya Health Promotion Model (HPM) oleh Pender melalui 2 teori yaitu mengenai teori nilai harapan dan teori kognitif sosial. Teori nilai harapan (expectancy value) adalah pemahaman bahwa perilaku sehat bersifat rasional dan ekonomis, yaitu : hasil tindakan bersifat rasional dan ekonomis dan pengambilan tindakan untuk menyempurnakan hasil yang diinginkan. Teori kognitif sosial (Social Cognitive Theory) menekankan pengarahan diri, pengaturan diri, dan persepsi terhadap kemajuan diri. Teori ini mengemukakan bahwa manusia memiliki kemampuan dasar antara lain : pengalaman sebagai petunjuk dimasa 

pengaturan diri dan refleksi diri. Pengambilan keputusan, tindakan dan efficacy diri akan menentukan status kesehatan orang (Alligood et al., 2017).

Penelitian dilakukan dengan metode desain penelitian kuantitatif menggunakan quasy experiment dengan menggunakan rancangan quasy experiment pre-post-test dengan control group. Pengumpulan data penelitian ini dilakukan dengan tahapan proses yaitu; persiapan meliputi ijin penelitian dari komite etik STIK Sint Carolus Jakarta, persiapan instrumen penelitian. Pelaksanaan meliputi pemberiaan informed consent, pretest kepatuhan pembatasan cairan dinilai dengan kusioner kepatuhan, menghitung nilai IDWG dilanjutkan pelatihan training efikasi diri. Pada tahap posttest dengan mengisi kembali kuesioner Kepatuhan dan menghitung nilai IDWG.

Populasi dalam penelitian ini adalah semua pasien pasien GGK yang menjalani hemodiálisa di RS. Stella Maris Makassar. Responden dibagi menjadi 69 responden (75\%) kelompok intervensi Training Efikasi Diri dan 23 responden (25\%) kelompok kontrol. Pengambilan sampel pada penelitian ini dilakukan dengan menggunakan teknik simple random sampling. Dalam penelitian ini sampel frame (kriteria sampel) Kriteria Inklusi yaitu : Pasien yang bersedia menjadi responden dengan bukti menandatangani Informed Consent, Pasien yang di diagnosa CKD oleh dokter dengan HD, Pasien yang mampu memahami dan mengikuti instruksi verbal sederhana, 
Pasien yang berusia $\geq 18$ tahun, Pasien dengan kondisi sadar penuh sehingga memungkinkan partisipasi dalam penelitian, Dapat ditimbang berat badannya dengan berdiri. Kriteria Ekslusi Pasien dengan hemodinamik tidak stabil misalnya: sesak napas.

Instrumen penelitian training efikasi diri dengan menggunakan Booklet. Kepatuhan pembatasan cairan dinilai dengan menggunakan kuesioner kepatuhan (Wulan \& Emaliyawati, 2018) sebelum dan sesudah penelitian pada kedua kelompok penelitian. Nilai IDWG dinilai dengan berdasarkan data berat badan yang diukur setiap kali kunjungan hemodialisa baik dikelompok intervensi maupun control.

Analisa statistik dianalisis menggunakan uji Chi-square untuk menilai distribusi karakteristik responden pada kedua kelompok penelitian serta untuk mengetahui hubungan yang signifikan antara masing-masing variable dependen dan variabel independen. T Dependen Parametrik (Uji Beda Dua Mean Dependen/Paired) untuk mengetahui kepatuhan Pembatasan cairan dan nilai IDWG pasien GGK sebelum dan sesudah mengikuti pelatihan training efikasi diri serta membandingkan kepatuhan Pembatasan cairan dan nilai IDWG pasien GGK sebelum dan sesudah mengikuti pelatihan training efikasi diri. Uji T Independent Parametrik (Uji Beda Dua Mean Independen) digunakan untuk menganalisis perbedaan kepatuhan pembatasan cairan dan nilai IDWG antara kelompok intervensi training efikasi diri dengan kelompok control. Analisis multivariat menggunakan uji ancova bertujuan mengetahui: besarnya kontribusi yang diberikan 
variabel independen secara simultan terhadap variabel-variabel dependent, besarnya pengaruh setiap variabel independent secara parsial terhadap variabel-variabel dependent, besarnya pengaruh variabel independen secara simultan terhadap variabel-variabel dependent dan variabel independent yang memberikan pengaruh paling besar terhadap variabel-variabel dependent (Susilo,2014; Hastono, 2016; Supardi \& Rustika, 2013).

\section{Karakteristik responden}

Distribusi responden GGK dengan HD yang memiliki presentase tersebar yaitu usia 51-60 tahun 52,2\%, jenis kelamin laki-laki $60,9 \%$, lama menjalani HD $\leq 2$ tahun 60,9\%. Distribusi karakteristik responden GGK dengan HD (kelompok umur, jenis kelamin, dan lama HD) pada kedua kelompok penelitian tidak berbeda ( $p>0.05)$.

\section{Perbedaan kepatuhan pembatasan cairan sebelum dan sesudah}

\section{dilakukan Training Efikasi Diri}

Tabel 1 Analisa Perbedaan Kepatuhan Pembatasan Cairan Sebelum Dan Sesudah Dilakukan Training Efikasi Diri Pasien Gagal Ginjal Kronik

\begin{tabular}{lccc}
\hline \multicolumn{1}{c}{ Variabel } & Mean & N & Std. Dev \\
\hline Kepatuhan Pembatasan Cairan pre & 40,23 & 69 & \\
\hline Kepatuhan Pembatasan Cairan post & 47,64 & 69 & \\
\hline
\end{tabular}

Didapatkan nilai $\mathrm{P}$ value sebesar $0,000<0.05$ yang artinya terdapat perbedaan antara kepatuhan pembatasan cairan sebelum dan sesudah dilakukan Training Efikasi Diri. 
Tabel 2. Analisa Perbedaan Kepatuhan Pembatasan Cairan Antara Kelompok Intervensi Dan Kontrol Sebelum Dan Sesudah Dilakukan Training Efikasi Diri Pasien

\begin{tabular}{llccc}
\hline \multicolumn{1}{c}{ Variabel } & Kelompok & $\mathrm{n}$ & Mean & Std. Deviation \\
\hline Kepatuhan Pembatasan & Intervensi & 69 & 40,23 & 3,934 \\
\cline { 2 - 5 } Cairan pre & Kontrol & 23 & 40,43 & 1,950 \\
\hline Kepatuhan Pembatasan & Intervensi & 69 & 47,64 & 5,889 \\
\cline { 2 - 5 } Cairan post & Kontrol & 23 & 39,43 & 3,964 \\
\hline
\end{tabular}

Dari hasil uji beda di dapatkan nilai $P$ value untuk kepatuhan pembatasan cairan pre pada kelompok kontrol dan intervensi sebesar 0,813 >0.05 yang artinya tidak terdapat perbedaan antara kepatuhan pembatasan cairan pre pada kelompok kontrol dan intervensi. Sedangkan kepatuhan pembatasan cairan post pada kelompok kontrol dan intervensi sebesar 0,000 $<0.05$ yang artinya terdapat perbedaan antara kepatuhan pembatasan cairan post pada kelompok kontrol dan intervensi sebelum dan sesudah dilakukan Training Efikasi Diri.

\section{Perbedaan Uji Nilai Intradialytic Weight Gain sebelum dan sesudah dilakukan Training Efikasi Diri}

Tabel 3. Perbedaan Nilai Intradialytic Weight Gain Sebelum Dan Sesudah DilakukanTraining Efikasi Diri Pasien Gagal Ginjal Kronik

\begin{tabular}{clrrr}
\hline Variabel & Mean & N & Std. Deviation & P value \\
\hline Nilai IDWG pre & 3,2813 & 69 & 0,79117 & \multirow{2}{*}{0.000} \\
\cline { 1 - 4 } Nilai IDWG post & 2,3464 & 69 & 0,92825 & \\
\hline
\end{tabular}

Dari hasil uji beda Nilai Intradialytic Weight Gain sebelum dan sesudah dilakukan Training Efikasi Diri didapatkan nilai $\mathrm{P}$ value 
sebesar $0,000<0.05$ yang artinya terdapat perbedaan antara Nilai Intradialytic Weight Gain sebelum dan sesudah dilakukan Training Efikasi Diri, sehingga pemberian edukasi menurunkan nilai IDWG.

Tabel 4. Perbedaan Nilai Intradialytic Weight Gain (IDWG) Sebelum Dan Sesudah Intervensi Training Efikasi Diri Pada Kelompok Intervensi Dan Kontrol

\begin{tabular}{lllrrl}
\hline Variabel & Kelompok & $\mathrm{n}$ & & $\begin{array}{c}\text { Std. } \\
\text { Deviation }\end{array}$ & Pvalue \\
\cline { 1 - 5 } Nilai IDWG pre & Intervensi & 69 & 3,2813 & 0,79117 & 0.226 \\
\cline { 2 - 5 } & Kontrol & 23 & 3,0217 & 1,12288 & \\
\hline \multirow{2}{*}{ Nilai IDWG post } & Intervensi & 69 & 2,3464 & 0,92825 & \multirow{2}{*}{0.000} \\
\cline { 2 - 5 } & Kontrol & 23 & 3,2174 & 0,97498 & \\
\hline
\end{tabular}

Dari hasil uji beda di dapatkan nilai $P$ value untuk Nilai Intradialytic Weight Gain pre pada kelompok kontrol dan intervensi sebesar 0,226 > 0.05 yang artinya tidak terdapat perbedaan antara Nilai Intradialytic Weight Gain pre pada kelompok kontrol dan intervensi sebelum dan sesudah dilakukan Training Efikasi Diri. Sedangkan Nilai Intradialytic Weight Gain post pada kelompok kontrol dan intervensi sebesar $0,000<0.05$ yang artinya terdapat perbedaan antara Nilai Intradialytic Weight Gain post pada kelompok kontrol dan intervensi sebelum dan sesudah dilakukan Training Efikasi Diri, hal ini berarti ada penurunan Nilai Intradialytic Weight Gain pada kelompok intervensi sementara pada kelompok kontrol tidak terjadi penurunan. 


\section{Pengaruh Training Efikasi Diri, usia, jenis kelamin dan lama HD} terhadap kepatuhan pembatasan cairan

Tabel 5. Pengaruh Training Efikasi Diri, Usia, Jenis Kelamin Dan Lama HD Terhadap Kepatuhan Pembatasan Cairan

\begin{tabular}{lccccc}
\hline \multicolumn{7}{c}{ Dependent Variable: Kepatuhan Pembatasan Cairan post } \\
\hline Source & $\begin{array}{c}\text { Type III Sum of } \\
\text { Squares }\end{array}$ & Df & $\begin{array}{c}\text { Mean } \\
\text { Square }\end{array}$ & F & Sig. \\
\hline Corrected Model & $3,050^{\text {a }}$ & 4 & 0,763 & 4,672 & 0,002 \\
\hline Intercept & 8,499 & 1 & 8,499 & 52,069 & 0,000 \\
\hline Usia & 0,003 & 1 & 0,003 & 0,019 & 0,892 \\
\hline Jenis kelamin & 0,028 & 1 & 0,028 & 0,173 & 0,678 \\
\hline Lama HD & 0,713 & 1 & 0,713 & 4,370 & 0,040 \\
\hline Pelatihan efikasi diri & 1,578 & 1 & 1,578 & 9,667 & 0,003 \\
\hline Error & 14,200 & 87 & 0,163 & & \\
\hline Total & 299 & 92 & & & \\
\hline Corrected Total & 17,250 & 91 & & \\
\hline a. R Squared $=, 177$ (Adjusted R Squared =,139) & & & \\
\hline
\end{tabular}

Dari tabel di atas hasil berdasarkan uji Ancova pelatihan efikasi diri serta variabel counfonding terhadap kepatuhan pembatasan cairan, didapatkan hasil corrected model 0,002 yang artinya pelatihan efikasi diri serta variabel counfonding secara bersama sama atau simultan mempengaruhi kepatuhan pembatasan cairan. Sedangkan secara parsial didapatkan variabel usia 0.892, jenis kelamin 0.678, lama HD 0,040 dan pelatihan efikasi diri 0,003. Hal ini dapat diartikan bahwa pelatihan efikasi diri dan lama HD sangat berpengaruh terhadap kepatuhan pembatasan cairan. Hasil analisis menujukkan bahwa variabel lama HD memodisikasi/menguatkan pengaruh pelatihan efikasi terhadap kepatuhan pembatasan cairan. Pelatihan 
efikasi diri dan lama HD mempengaruhi kepatuhan pembatasan cairan sebanyak $17,7 \%$, sementara $82,3 \%$ dipengaruhi oleh variabel lain di luar penelitian. Sedangkan didapatkan nilai error 0,163 yang artinya model multivariat semakin baik.

5. Pengaruh Training Efikasi Diri, usia, jenis kelamin dan lama HD terhadap Nilai Intradialytic Weight Gain

Tabel 6. Pengaruh Training Efikasi Diri, Usia, Jenis Kelamin Dan Lama HD Terhadap Nilai Intradialytic Weight Gain

\begin{tabular}{lcrrrr}
\hline \multicolumn{7}{c}{ Dependent Variable: Nilai IWGD Post } \\
\hline Source & $\begin{array}{c}\text { Type III Sum of } \\
\text { Squares }\end{array}$ & Df & $\begin{array}{c}\text { Mean } \\
\text { Square }\end{array}$ & F & Sig. \\
\hline Corrected Model & $3,375^{\text {a }}$ & 4 & 0,844 & 4,949 & 0,001 \\
\hline Intercept & 8,948 & 1 & 8,948 & 52,487 & 0,000 \\
\hline Usia & 0,005 & 1 & 0,005 & 0,027 & 0,871 \\
\hline Jenis kelamin & 0,074 & 1 & 0,074 & 0,433 & 0,512 \\
\hline Lama HD & 0,869 & 1 & 0,869 & 5,099 & 0,026 \\
\hline Pelatihan efikasi diri & 1,958 & 1 & 1,958 & 11,487 & 0,001 \\
\hline Error & 14,832 & 87 & 0,170 & & \\
\hline Total & 293,000 & 92 & & & \\
\hline Corrected Total & 18,207 & 91 & & & \\
\hline a. R Squared $=, 185$ (Adjusted R Squared $=, 148)$ \\
\hline
\end{tabular}

Dari tabel di atas hasil berdasarkan uji Ancova pelatihan efikasi diri serta variabel counfonding terhadap Nilai Intradialytic Weight Gain, didapatkan hasil corrected model 0,001 yang artinya pelatihan efikasi diri serta variabel counfonding secara bersama sama atau simultan mempengaruhi Nilai Intradialytic Weight Gain. Sedangkan secara parsial didapatkan variabel usia 0.871 , jenis kelamin 0.512 , lama HD 0,026 dan pelatihan efikasi diri. 0,001. Hal ini dapat diartikan bahwa pelatihan efikasi diri serta lama HD sangat berpengaruh terhadap Nilai Intradialytic Weight Gain. Pelatihan 
efikasi diri dan lama HD mempengaruhi Nilai Intradialytic Weight Gain sebanyak $18,5 \%$, sementara $81,5 \%$ dipengaruhi oleh variabel lain diluar penelitian. Sedangkan didapatkan nilai eror 0,170 yang artinya model multivariat semakin baik.

\section{PEMBAHASAN}

Kasus GGK tinggi pada usia lanjut disebabkan karena multi faktor antara lain diabetes mellitus, hipertensi, medikasi (agen toksik), batu ginjal, yang kebanyakan didapatkan pada pertengahan dan usia lanjut 55-65 tahun (Black, Joyce M \& Hawks, 2017). Penelitian Lebov et al., (2015) mayoritas responden yang didiagnosa GGK adalah rentang usia 30-39 tahun (31.8\%), 40-49 tahun (19,9\%) dan usia 50-70 tahun (24\%) 50-70 tahun. Penelitian (Victor \& Wokoma, 2019) yang menyatakan rata-rata pasien yang didiagnosa GGK adalah pada usia 22-80 tahun.

Distribusi jenis kelamin pada penelitian ini yang terbanyak adalah laki-laki, Hal ini sesuai dengan data angka kejadian GGK menurut Pusat Data dan Informasi Kemenkes RI, (2017) yaitu jenis kelamin laki-laki $(0,3 \%)$ lebih tinggi dari perempuan $(0,2 \%)$. Berbeda dengan prevalensi GGK di Amerika lebih umum terjadi pada perempuan daripada laki-laki. Perkembangan penyakit ginjal pada wanita lebih lambat disebabkan oleh pola makan, perbedaan struktur ginjal, respons hemodinamik terhadap stress dan hormon seks. Perempuan memiliki hormon estrogen lebih banyak, dimana hormon estrogen dapat mempengaruhi kadar kalsium dalam tubuh 
dengan menghambat pembentukan sitokin tertentu untuk menghambat osteoklas agar tidak berlebihan dalam menyerap tulang. Kalsium memiliki efek protektif dengan mencegah penyerapan oksalat yang bisa membentuk batu ginjal yang merupakan salah satu penyebab terjadinya gagal ginjal kronik pada laki-laki (Ratnawati, 2016). Penelitian ini didukung dengan temuan dimana jumlah pasien pria lebih banyak menderita GGK dibandingkan wanita yang disebabkan beberapa hal, salah satu diantaranya yaitu pembesaran prostat menyebabkan terjadinya obstruksi dan infeksi yang dapat berkembang menjadi gagal ginjal (S. C. Smeltzer \& Bare, 2013).

Lama menjalani Hemodialisa pada penelitian ini lebih banyak yaitu HD $\leq 2$ tahun 60,9\%. Hal ini hampir sama dengan penelitian yang dilakukan oleh (Rambod \& Rafii, 2010) bahwa dari 202 pasien yang menjalani hemodialisa 2 kali seminggu dengan lama hemodialisa 5 jam di Iran didapatkan data hemodialisa $<12$ bulan sebanyak 13 (6,4\%), 12-24 bulan sebanyak 57 pasien atau 25,8\% dan $>24$ bulan sebanyak $137(67,8 \%)$.

Secara statistik menunjukkan ada pengaruh yang signifikan untuk intervensi training efikasi diri terhadap kepatuhan pembatasan cairan. Temuan ini sejalan dengan hasil penelitian yang dilakukan oleh Hasil penelitian ini sejalan dengan penelitian yang dilakukan oleh (Susilawati et al., 2018) Hasil penelitian menunjukkan hubungan dengan kepatuhan pembatasan intake cairan pasien hemodialisis mempunyai hubungan yang signifikan, artinya semakin baik efikasi 
diri pasien maka akan semakin tinggi kepatuhan pasien dalam membatasi asupan cairan. Penelitian yang dilakukan oleh (Anita \& Novitasari, 2017) Berdasarkan uji statistik dengan teknik Spearman Rank didapatkan nilai signifikansi 0,033 $(p<0,05)$. Hasil tersebut bermakna bahwa terdapat hubungan yang positif antara lama hemodialisa dengan kepatuhan pembatasan asupan cairan. Hasil penelitian ini didukung oleh peneliti sebelumnya yang dilakukan oleh (Ratnawati, 2016) yang menunjukkan bahwa adanya hubungan antara lama menjalani hemodialisa dengan kepatuhan pembatasan asupan cairan. Penelitian ini juga mendukung hasil penelitian yang dilakukan oleh (Manguma et al., 2014) yang menunjukkan bahwa ada ubungan antara lamanya hemodialisa dengan kepatuhan pasien dalam menjalani program terapi hemodialisa.

Self efficacy adalah dasar dari motivasi manusia, prestasi dan kesejahteraan emosional. Teori self efficacy didasarkan pada harapan seseorang berkaitan dengan rangkaian tindakan tertentu. Menurut (Bandura \& A, 2006) menyebutkan bahwa ada empat proses pembentukan self eficacy yaitu proses kognitif, proes motivasional, proshes afektif, dan seleksi yang berlangsung sepanjang kehidupan. Proses kognitif akan mempengaruhi bagaimana pola pikir yang akan mendorong atau menghambat perilaku individu.

Secara statistik menunjukkan ada pengaruh yang signifikan untuk intervensi training efikasi diri terhadap nilai IDWG. Penelitian ini sejalan dengan penelitian yang dilakukan oleh (Saefulloh \& Nuraeni, 2016) Hasil penelitian menunjukkan pemberian edukasi 
terstruktur pada kelompok intervensi meningkatkan self efficaccy untuk mengontrol intake cairan antar waktu dialysis $(p=0,000$, $\alpha=0,05)$, dan menurunkan IDWG $(p=0,04, \alpha=0,05)$. Edukasi terstruktur berpengaruh dalam menurunkan IDWG. Hasil penelitian yang dilakukan oleh (Priska \& Herlina, 2013) pada pasien gagal ginjal kronik di RSUD Pasar Minggu, dimana hasil penenlitian ini mengungkapkan hasil pengamatan selama 1 bulan dengan jumlah pasien 40 orang. Uji statistic menggunakan Man Whitney test menunjukkan adanya hubungan antara efikasi diri dengan IDWG $(p=0.001, \alpha=0,05)$.

Hasil penelitian lain yang dilakukan oleh (Aliasgharpour et al., 2012) menunjukkan bahwa melaksanakan program pelatihan promosi self-efficacy adalah efektif dalam mengurangi berat badan dan meningkatkan self-efficacy pada pasien yang menjalani hemodialisis. Menurut teori efikasi diri merupakan kepercayaan diri sendiri terhadap kemampuan diri, dalam berfikir, berprilaku dan memotivasi dirinya sendiri, berhasil tidaknya hal yang dilakukan tergantung bagimana individu menila kemampuannya sendiri atas apa yang ingin dicapai serta suatu aspek pengetahuan tentang diri atau self knowledge yang paling berpengaruh dalam kehidupan manusia sehari-hari. Keyakinan akan seluruh kemampuan ini meliputi kepercayaan diri, kemampuan menyesuaikan diri, kapasitas kognitif, kecerdasan dan kapasitas bertindak pada situasi yang penuh tekanan. Efikasi diri yang dimiliki ikut mempengaruhi individu dalam menentukan tindakan yang akan dilakukan untuk mencapai suatu 
tujuan termasuk di dalamnya perkiraan berbagai kejadian yang akan dihadapi (Baanu \& Oyelekan, 2016). Individu yang memiliki efikasi yang tinggi akan melakukan tugas-tugas sulit dan akan menganggapnya sebagai tantangan bukan sebagai hal yang harus dihindari. Individu akan meningkatkan dan mempertahankan dirinya dalam menghadapi kegagalan dan dengan cepat memulihkan keadaan. Pandangan yang positif akan mampu menghasilkan pencapaian sebagai pribadi yang optimis sehingga mengurangi stress dan menurunkan kerentanan depresi, namun bila sebaliknya maka artinya individu memiliki aspirasi yang rendah dan komitmen yang lemah dalam tujuan yang ingin dicapai (Ghufron, 2014). Maka dapat disimpulkan bahwa efikasi diri adalah keyakinan dan kemantapan individu, memperkirakan kemampuan yang ada yang menghasilkan perilaku yang diusahakan sehingga tercapai tujuan yang diinginkan

Kaitannya dengan aplikasi teori model Pender teori Helath Promotion Model (HPM) atau Model Promosi Kesehatan, konsep model berdasarkan upaya pada pemberdayaan kemampuan individu atau keluarga untuk meningkatkan derajat kesehatan dan kualitas hidupnya. HPM membantu perawat dalam menolong pasien mengidentifikasi faktor risiko terhadap kesehatan dan perilaku sehat yang sudah pernah dilakukan dalam rangka membentuk perilaku baru yang dapat mencapai status kesehatan yang optimal (Alligood et al., 2017). Peran perawat dalam promosi kesehatan Nola Pender adalah mencegah GGK ke kondisi yang lebih buruk, dengan mengajak individu dan peran serta lingkungan agar berperilaku positip 
terhadap pemeliharaan dan peningkatan kesehatan, meningkatkan motivasi dan komitmen pasien GGK agar lebih patuh terhadap pembatasan cairan.

Kaitannya kepatuhan pembatasan cairan dan nilai IDWG dengan aplikatif model teori HPM yaitu dalam hubungan mengubah perilaku kuratif kearah perilaku promotif dan rehabilitatif. Manusia mempunyai kapasitas untuk merefleksikan kesadaran dirinya, termasuk penilaian terhadap kemampuannya, menilai perkembangan sebagai suatu nilai yang positif dan mencoba mencapai keseimbangan antara perubahan dan stabilitas. (Alligood et al., 2017). Pasien dalam upaya memenuhi kepatuhan pembatasan cairan dibutuhkan peran dari perawat sebagai educator dan konsultan. Pasien yang memiliki keluhan ataupun ingin mengungkapkan perasaannya entah karena ada beban ataupun hanya ingin bercerita selama menjalani HD dapat dilakukan pada tahapan Training Efikasi Diri serta lewat observasi selama penelitian dan pasien menunjukkan perilaku baik yang meningkatkan kesehatannya.

Training efikasi diri dapat membantu meningkatkan kepatuhan pembatasan cairan dan menurunkan nilai IDWG penderita GGK dengan hemodialisa. Berdasarkan hasil penelitian ini disarankan untuk melakukan penelitian efektivitasi Training efikasi diri terhadap kepatuhan Pembatasan cairan dan nilai IDWG dalam waktu yang lebih lama (>4 minggu) dengan jumlah sampel yang lebih besar dan menggunakan lebih dari satu Rumah Sakit. 


\section{DAFTAR PUSTAKA}

Afandi, A. T. \& E. H. K. (2017). Efektivitas Self Efficacy Terhadap Kualitas Hidup Klien dengan Diagnosa Penyakit Kronik. 23-30. http://repository.unej.ac.id/handle/123456789/80263

Alligood, Martha, \& R. (2017). Nursing Theorists and Their Work (Eighth Edi). Elsivier Mosby.

Black, J. M., \& Hawks, J. H. (2014). Keperawatan Medikal Bedah (8th ed.). Salemba Medika.

Brunner, \& Suddarth. (2013). Keperawatan Medikal Bedah. EGC.

Friedman, M. M. (2018). Buku acar keperawatan keluarga: Riset, teori dan praktik. EGC.

Hastono, P. S. D. D. (2016). Analisa Data Pada Bidang Kesehatan. PT RajaGrafindo Prasada.

Hill, R. Hall, H., \& J. P, G. (2017). Fundamentals of Nursing and Midwifery: A Person-Centred Approach to Care.

Huether, S. E., L., M., \& Kathryn. (2019). Buku Ajar Patofisiologi (6th ed.). Elsevier.

Istanti, Y. P. (2011). Faktor-Faktor yang Berkontribusi terhadap Interdialytic Weight Gains pada Pasien Chronic Kidney Diseases yang Menjalani Hemodialisis Factors that Contribute to Interdialytic Weight Gains on Chronic Kidney Diseases Patients Undergoing Haemodialysis. Artikel Penelitian, 11, 118-130.

Lewis, Dirksen, Heitkemper, Bucher, \& Camera. (2011). MedicalSurgical Nursing Asessment and Management Of Clinical Problems (8th ed.). Elsevier.

Mailani, F., \& Andriani, R. F. (2017). Hubungan Dukungan Keluarga Dengan Kepatuhan Diet Pada Pasien Gagal Ginjal Kronik Yang Menjalani Hemodialisis. Jurnal Endurance, 2(3), 416. 
Mohebi, S., Gharlipour, Z., Sharifirad, G., \& Ramezani, T. (2018). Effect of Educational Intervention Based on Self-efficacy Theory on Adherence to Dietary and Fluids-intake Restriction in Hemodialysis Patients. 6(1), 31-38.

Morton, R. L., Snelling, P., Webster, A. C., Rose, J., Masterson, R., Johnson, D. W., \& Howard, K. (2012). Factors influencing patient choice of dialysis versus conservative care to treat end-stage kidney disease. Cmaj, 184(5), 277-283. https://doi.org/10.1503/cmaj.111355

Mustikasari, I., \& Noorratri, E. D. (2017). Faktor-Faktor yang Mempengaruhi Nilai Interdialytic Weight Gain Pasien Hemodialisa di RSUD Panembahan Senopati Bantul. Jurnal Kesehatan Gaster, 15(1), 78-86. https://doi.org/https://doi.org/10.30787/gaster.v15i1.139

Neumann, C. L., Wagner, F., Menne, J., Brockes, C., SchmidtWeitmann, S., Rieken, E. M., Schettler, V., Hagenah, G. C., Matzath, S., Zimmerli, L., Haller, H., \& Schulz, E. G. (2013). Body weight telemetry is useful to reduce interdialytic weight gain in patients with end-stage renal failure on hemodialysis. Telemedicine and E-Health, 19(6), 480-486. https://doi.org/10.1089/tmj.2012.0188

Nurudin, A., \& Sulistyaningsih, D. R. (2018). Hubungan Antara Lama Menjalani Terapi Hemodialisis Ginjal Kronik. 1(1), 1-7.

Priska, N. P., \& Herlina, S. (2013). Artikel Penelitian. 2014, 2-31. http://journals.stikim.ac.id/index.php/jiiki/article/view/226/223

Rahimi, F., Oskouie, F., Naser, O., Sanandji, M. E., \& Gharib, A. (2017). The effect of self-care on patients undergoing Hemodialysis in the Sanandaj Hospitals affiliated to Kurdistan University of Medical Sciences in 2016. Bali Medical Journal, 6(3), 684. https://doi.org/10.15562/bmj.v6i3.707 
Ratnawati, R. (2016). Hubungan Dukungan Keluarga Dengan Kepatuhan Berobat Penderita Skizofrenia. VI(November), 416423.

Riskesdas. (2018). Kementrian Kesehatan Badan Penelitian dan Pengembangan.

Setiati, S., Idrus, A., Sudoyo, W. A., K. Simadibrata, M., Setiyonadi, B., \& Syam, F. A. (2017). Buku Ajar Ilmu Penyakit Dalam (VI). Internal Publishing.

Sharaf, A. Y. (2016). The impact of educational interventions on hemodialysis patients ' adherence to fluid and sodium restrictions . IOSR Journal of Nursing and Health Science Ver. II, 5(3), 50-60. https://doi.org/10.9790/7388-0603025060

Sherwood, L. (2017). Fisiologi Manusia Dari Sel ke Sistem (8th ed.). EGC.

Smeltzer, S., \& Bare, B. G. (2010). Buku AJar Keperawatan Medikal Bedah. EGC.

Smeltzer, S. C., \& Bare, B. G. (2013). Buku Ajar Keperawatan Medikal Bedah Brunner dan Suddarth (8th ed.). EGC.

Sulistyaningsih, D. (2012). Efektivitas Training Efikasi Diri Pada Pasien Penyakit Ginjal Kronik Dalam Meningkatkan Kepatuhan Terhadap Intake Cairan. Majalah IImiah Sultan Agung, 50(128), 11-25.

Syamsiah, N. (2011). Faktor-Faktor Yang Berhubungan dengan Kepatuhan Pasien CKD yang Menjalani Hemodialisa di RSPAU Dr Esnawan Antariksa Halim Perdana Kusuma Jakarta.

Tayebi, A., Einollahi, B., Rahimi, A., \& Sirati-nir, M. (2019). The Nonadherence with Treatment in Dialysis Patients in Iran, A Systematic Review. 13(6), 347-362. 
Victor, O. N., \& Wokoma, F. S. (2019). Prevalence and Pattern of Mineral Bone Disease in Patients with Chronic Kidney Disease in. International Journal of Advances in Nephrology Research, 2(1), 1-8.

Wijayanti, W., Isroin, L., Purwanti, L. E., \& Kunci, K. (2017). Analisis Perilaku Pasien Hemodialisis dalam Pengontrolan Cairan Tubuh. Indonesian Journal for Health Sciences, 1(1), 10-16.

Williams, A. P. (2018). Study Guide for Dewit's Fundamental Concepts and Skills for Nursing-E-Book (5th ed.). Elsevier Health Sciences.

Wulan, S. N., \& Emaliyawati, E. (2018). Kepatuhan Pembatasan Cairan dan Diet Rendah Garam (Natrium) pada Pasien GGK yang Menjalani Hemodialisa. Faletehan Health Journal, 5(3), 99-106. https://doi.org/10.33746/fhj.v5i3.15 